\title{
A METHOD FOR THE DETERMINATION OF L-LACTIC ACID
}

\author{
KAKUO KITAHARA, TETSUO HIYAMA, AIKO TAI \\ AND SHÔJI MIZUSHIMA \\ Institute of Applied Microbiology, \\ University of Tokyo, Tokyo \\ Received January 11, 1964
}

Though several good methods for the determination of the total amount of lactic acid have been published $(1,2)$, there are not many reliable methods for the separate determination of $\mathrm{D}(-)$ - or $\mathrm{L}(+)$-lactic acid. The usual method is the determination of the water content and the optical rotation of the zinc salt(3). An enzymatic determination of D-lactic acid with the lactate oxidizing system from Leuconostoc mesenteroides (4), Lactobacillus plantarum (5) or Escherichia coli (6) is often used, while for L-lactic acid a spectrophotometric determination of $\mathrm{NADH}_{2}$ caused by the hydrogenation of NAD by L-lactate and L-lactate dehydrogenase has also been used $(7,8,9)$. Besides these methods, a microbiological assay for $\mathrm{D}-\alpha$ hydroxy acids was presented by CAMIEN and DunN (11 13).

In 1952, Kitahara and Fukui (5) pointed out the possibility of the manometric determination of L-lactic acid using the oxidase preparation from Lactobacillus saké. The method described herein is based on the observation that dried cells of $L$. saké oxidized only L-lactate in the presence of methylene blue, even with preparations containing D- and L-lactate dehydrogenases. When a lactic acid-containing sample is incubated with the dried cells and methylene blue in Warburg apparatus, the oxygen consumption is a measure of the amount of L-lactic acid in the sample.

\section{MATERIALS AND METHODS}

Preparation of dried cells. The strain used was Lactobacillus saké G01 which was isolated in our laboratory from "starter" of Japanese Saké(16). The strain was kept on malt-bouillon agar containing solid calcium carbonate. The cells were cultivated at $30^{\circ}$ in a medium which contained $2 \%$ glucose, $1 \%$ peptone, $0.6 \%$ yeast extract, $2 \%$ sodium acetate (anhydrous) and the following inorganic salts ; $0.02 \%$ sodium chloride, $0.02 \%$ magnesium chloride and $0.002 \%$ manganese chloride. The cells were harvested at the early stage of the stationary phase, washed twice with $0.5 \%$ saline and dried over $\mathrm{P}_{2} \mathrm{O}_{5}$ in vacuo at room temperature. The total yield of dried cells was about $0.6 \mathrm{~g}$ per liter of the medium. The dried cells were used for the determination of L-lactic acid and could be stored in a desicator at $4^{\circ}$ for more than several months without any loss of the dehydrogenase activity. 
Standard assay method. For the determination of L-lactic acid, Warburg vessels were used. The centre well contained $0.2 \mathrm{ml}$ of $20 \% \mathrm{KOH}$, the side arm $0.2 \sim 0.6 \mathrm{ml}$ of a sample (containing L-lactate, $2 \sim 10 \mu$ moles) and the main compartment $10 \mathrm{mg}$ dried cells, $0.2 \mathrm{ml}$ of $0.1 \%$ methylene blue and $0.2 \mathrm{~m}$ phosphate buffer ( $\mathrm{pH} 6.5$ ), the final volume in the whole vessel being $2.2 \mathrm{ml}$.

Gas phase was air, the incubation temperature was $30^{\circ}$, and shaking frequency was about 120 per min. The oxygen uptake was compared as usual with that in a vessel without sample (Fig. 1).

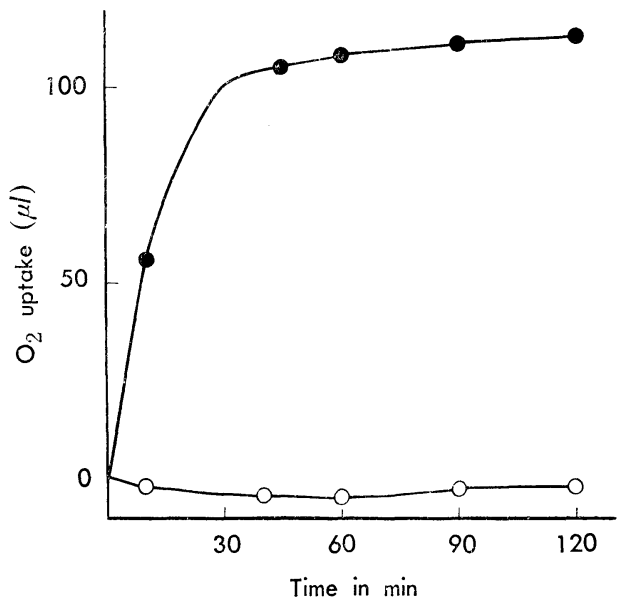

Fig. 1. Determination of L-lactate by dried cells in Warburg vessel.

Each Warburg vessel contained $10 \mathrm{mg}$ dried cells, $0.2 \mathrm{ml}$ of $1 \%$ methylene blue and $1.6 \mathrm{ml}$ of $0.2 \mathrm{M}$ phosphate buffer $(\mathrm{pH} 6.5)$ in main compartment, $0.2 \mathrm{ml}$ of $0.025 \mathrm{M}$ L-lactate $(5 \mu$ moles $)$ in side arm and $0.2 \mathrm{ml}$ of $20 \% \mathrm{KOH}$ in centre well. Total volume, $2.2 \mathrm{ml}$.

- - with L-lactate.

$\longrightarrow-\bigcirc-$ - without L-lactate.

Lactate preparation used. D- and L-lactic acid were prepared from the fermentation broth of Sporolactobacillus inulinus(17), and from that of Lactobacillus casei TA, respectively. Lithium DL-lactate was obtained commercially.

\section{RESULTS AND DISCUSSION}

\section{Enzymes in dried cells}

As will be reported in a separate article (14), cells grown in an acetatecontaining medium contained flavin nucleotide linked L-lactate dehydrogenase, while showing no activity of D-lactate dehydrogenase possessing flavin 
nucleotide. A sonic extract obtained from the cells did not possess NADlinked D- or L-lactate dehydrogenase in detectable amounts. Since a treatment of the cells with cold acetone did not bring about any loss of the L-lactate dehydrogenase activity, the preparation thus obtained could also be used for the determination.

When the cells were grown on a medium containing solid calcium carbonate $(1 \%)$ instead of sodium acetate, the cells exhibited D- and L-lactate dehydrogenases activity in the presence of 2, 6-dichlorophenolindophenol, both of these enzymes seemed to contain flavin nucleotide as the prosthetic group. However, only L-lactate dehydrogenase could react with methylene blue. This dehydrogenase also reacted with oxygen, but the rate was very slow. Although the cells possessed lactate racemization activity (15), this was lost by drying the cells over $\mathrm{P}_{2} \mathrm{O}_{5}$ in vacuo. Therefore, the cells grown on an acetate-free medium also could be used for the stereospecific determination of L-lactic acid, however, the yield of the cells was rather low.

\section{Substrate specificity}

Among $\alpha$-hydroxycarboxylic acids tested, DL- $\alpha$-hydroxybutyrate and glycolate as well as L-lactate were oxidized, though the late of oxidation of these compounds were less than one-seventh that of L-lactate. Compounds which were not oxidized were glucose, pyruvate, acetate and D-lactate. They had no influence either on the rate of L-lactate oxidation or on the

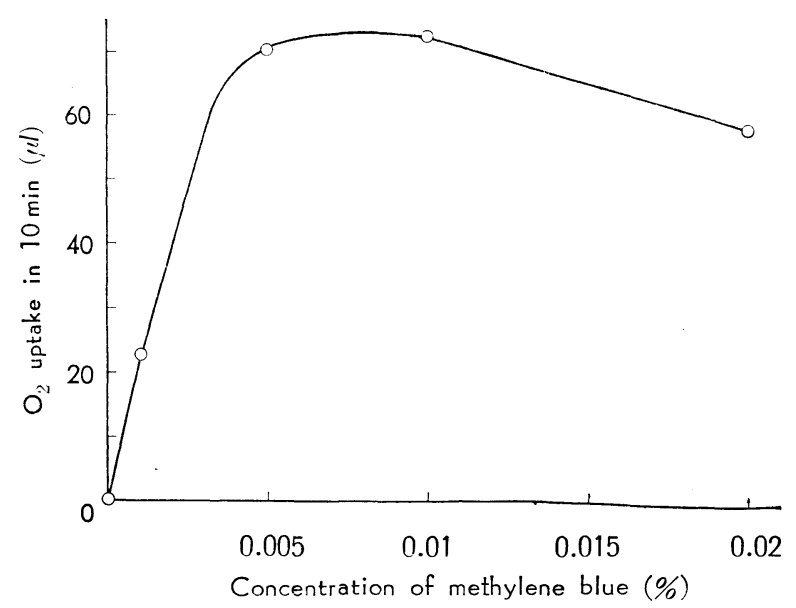

Fig. 2. Effect of concentration of methylene blue on L-lactate dehydrogenase activity.

Each Warburg vessel contained $10 \mathrm{mg}$ dried cells, $0.2 \mathrm{ml}$ of methylene blue and $1.6 \mathrm{ml}$ of $0.2 \mathrm{M}$ phosphate buffer $(\mathrm{pH} 7.0)$ in main compartment, $0.2 \mathrm{ml}$ of $0.025 \mathrm{M} \mathrm{Li}$-DL-lactate in side arm and $0.2 \mathrm{ml}$ of $20 \% \mathrm{KOH}$ in centre well. Total volume, $2.2 \mathrm{ml}$. Each value was obtained after subtraction of that of control experiment (lactate being absent). 
total oxygen uptake. This shows that the present method is excellent in the determination of L-lactate in a sample such as a fermentation broth.

Effect of the concentration of methylene blue on the L-lactate dehydrogenase activity

As shown in Fig. 2, the rate of the oxidation was critically dependent on the concentration of methylene blue, and the activity was inhibited at higher concentrations of this dye. The optimal concentration for the de-

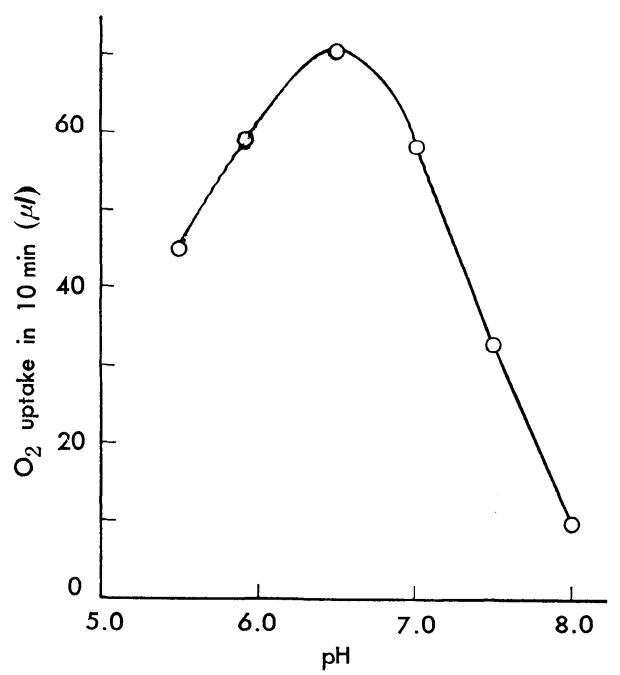

Fig. 3. Effect of $\mathrm{pH}$ on L-lactate dehydrogenase activity.

Each Warburg vessel contained $0.5 \mathrm{ml}$ of dried cells suspension (10 mg per $\mathrm{ml}$ distilled water), $0.2 \mathrm{ml}$ of $0.1 \%$ methylene blue and $1.1 \mathrm{ml}$ of $0.2 \mathrm{M}$ phosphate buffer in main compartment, $0.2 \mathrm{ml}$ of $0.05 \mathrm{M} \mathrm{Li}-\mathrm{DL}$-lactate in side arm and $0.2 \mathrm{ml}$ of $20 \%$ $\mathrm{KOH}$ in centre well. All values were obtained after subtraction of that of control experiment (lactate being absent).

Table 1. Stoichiometry of L-lactate oxidation.

\begin{tabular}{c|c|c|c|c}
\hline & $\begin{array}{c}\text { L-Lactate } \\
\text { added }\end{array}$ & $\begin{array}{c}\mathrm{O}_{2} \\
\text { consumed }\end{array}$ & $\begin{array}{c}\mathrm{CO}_{2} \\
\text { evolved }\end{array}$ & $\begin{array}{c}\text { Pyruvate } \\
\text { formed }\end{array}$ \\
\hline \begin{tabular}{c|c|c|c} 
Catalase \\
-
\end{tabular} & $5 \mu \mathrm{mole}$ & $4.95 \mu \mathrm{mole}$ & $4.26 \mu \mathrm{mol}$ & $0.37 \mu \mathrm{mol}$ \\
\hline $\begin{array}{c}\text { Catalase } \\
+\end{array}$ & 5 & 2.94 & - & 5.87 \\
\hline
\end{tabular}

The standard assay method described in text was applied.

Oxygen uptake and $\mathrm{CO}_{2}$ evolution were measured manometrically. After $\mathrm{O}_{2}$ uptake attained maximum, pyruvate in the reaction mixture was determined by the method of FriedemanN and HAUGEN (10). 
termination was found to be $0.005 \sim 0.01 \%$.

Effect of $p H$

The effect of $\mathrm{pH}$ on the dehydrogenase activity was studied in phosphate buffer (Fig. 3). The optimal $\mathrm{pH}$ was found to be 6.5.

Stoichiometry of the reaction

In Table 1 is shown the stoichiometry of L-lactate oxidation with or without catalase. From these results, the oxidation of L-lactate by the dried cells was considered to proceed as follows:

In the presence of catalase :

$$
\begin{aligned}
& \text { L-lactate }+\mathrm{O}_{2} \longrightarrow \text { pyruvate }+\mathrm{H}_{2} \mathrm{O}_{2} \\
& \mathrm{H}_{2} \mathrm{O}_{2} \longrightarrow \mathrm{H}_{2} \mathrm{O}+\frac{1}{2} \mathrm{O}_{2} \\
& \text { L-lactate }+\frac{1}{2} \mathrm{O}_{2} \longrightarrow \text { pyruvate }+\mathrm{H}_{2} \mathrm{O}
\end{aligned}
$$

In the absence of catalase:-

$$
\begin{aligned}
& \text { L-lactate }+\mathrm{O}_{2} \longrightarrow \text { pyruvate }+\mathrm{H}_{2} \mathrm{O}_{2} \\
& \text { pyruvate }+\mathrm{H}_{2} \mathrm{O}_{2} \stackrel{\text { non-enzymatically }}{\longrightarrow} \text { acetate }+\mathrm{H}_{2} \mathrm{O}+\mathrm{CO}_{2}
\end{aligned}
$$

$$
\text { L-lactate }+\mathrm{O}_{2} \longrightarrow \text { acetate }+\mathrm{H}_{2} \mathrm{O}+\mathrm{CO}_{2}
$$

Other electron acceptors

Among various electron acceptors tested, $\alpha$-naphthoquinone (final concentration $0.01 \%$ ) was active. Though the endogenous $\mathrm{O}_{2}$ uptake increased considerably, the late of the oxidation of L-lactate with $\alpha$-naphthoquinone was three times greater than that with methylene blue.

\section{SUMMARY}

A method of the determination of L-lactic acid is described. A dried cells or an acetone powder from Lactobacillus saké G01 in the presence of methylene blue oxidized L-lactic acid quantitatively and specifically. Oxygen consumption in a Warburg apparatus was used to determine the amount of L-lactic acid present in the sample.

\section{REFERENCES}

(1) T. E. Friedemann and J. B. Graeser: J. Biol. Chem., 100, 291 (1933).

(2) J. B. Barker and W. H. Summerson: J. Biol. Chem., 138, 535 (1941).

(3) C. P. Pederson, W. H. Peterson and E. B. Fred: J. Biol. Chem., 68, 151 (1926).

(4) K. Kitahara, S. Fukui and A. Obayashi: Symp. Enz. Chem. (Japan), 10, 210 (1954).

(5) K. Kitahara and S. Fukui: J. Agr. Chem. Soc. Japan, 26, 555 (1952).

(6) C. J. A. van. DenHamer and R. W. Elias: Biochim. Biophys. Acta, 29, 556 
(1958).

(7) G. Pfleiderer and K. Dose: Biochem. Z., 326, 436 (1955).

(8) H. D. Harn and F. H. Bruns: Biochim. Biophys. Aita, 21, 378 (1956).

(9) H. Holzer and H. D. Söling; Biochem. Z., 336, 201 (1962).

(10) T. E. Friedmann and G. E. Häugen: J. Biol. Chem., 149, 415 (1943).

(11) M. N. CAMIEN and M. S. DunN: J. Biol. Chem., 201, 621 (1953).

(12) M. N. CAMien and M. S. Dunn: J. Biol. Chem., 211, 593 (1954).

(13) M. N. Camien and M. S. Dunn: Proc. Soc. Exp. Biol. Med., 85, 177 (1954).

(14) KITAHARA et. al. in preparation.

(15) K. Kitahara, A. Obayashi and S. Fukui: Proc. Intern. Symp. Enz. Chem. Tokyo and Kyoto, 460 (1958).

(16) H. Katagiri, K. Kitahara and K. Fukami: Bull. Agr. Chem. Soc. Japan, 10, 156 (1934).

(17) K. Kitahara and J. Suzuki: J. Gen. Appl. Microbiol., 9, 59 (1963). 